\title{
Indek Pemahaman Hak-Hak Konstitusional Warga Negara di Kawasan Risiko Beneana Gunung Merapi di Kabupaten Sleman, D.I. Yogyakarta
}

\author{
Iwan Satriawan ${ }^{1}$, Agus Setyo Muntohar ${ }^{2}$, dan Sunarno Ibrahim ${ }^{3}$ \\ 1,3. Program Studi Hukum, Fakultas Hukum, Universitas Muhammadiyah Yogyakarta, Jl. Brawijaya, Kasihan, Bantul, Yogyakarta \\ 2 Fakultas Teknik, Universitas Muhammadiyah Yogyakarta, Jl. Brawijaya, Kasihan, Bantul, Yogyakarta \\ Jl. Brawijaya, Kasihan, Bantul, Yogyakarta 55183 \\ Email: iwansatriawan@umy.ac.id \\ DOI: 10.18196/ppm.37.269
}

\begin{abstract}
Abstrak
Tulisan ini mengkaji pengaturan hak-hak konstitusional warga negara di kawasan risiko bencana dan mengevaluasi tingkat pemahaman warga negara terhadap hak-hak konstitusionalnya dalam kondisi bencana dengan mengambil sampel kawasan rawan bencana Gunung Merapi, Yogyakarta. Kajian ini menggunakan metode studi kepustakaan dan penelitian lapangan dengan mengajukan daftar pertanyaan dalam bentuk kuesioner kepada responden. Hasil kajian menunjukkan bahwa pengaturan hak-hak konstitusional warga negara di kawasan rentan bencana sudah diatur dalam UUD 1945 dan berbagai peraturan perundangundangan yang ada di mana pemerintah pusat maupun daerah memiliki kewajiban untuk memenuhi hak-hak dasar warga negara dalam upaya penanggulangan pasca bencana. Namun demikian, karena ketidakpahaman warga negara yang terdampak bencana terkait hak-hak konstitusionalnya, tidak jarang pemerintah pusat maupun daerah baik dengan sengaja ataupun tidak sengaja lalai dalam memenuhi hak-hak konstitusional warga negara dalam penanggulangan pasca bencana tersebut. Oleh karena itu, diperlukan program peningkatan pemahaman hak-hak konstitusional warga negara di kawasan rawan bencana yang lebih masif agar warga negara terkait memahami hak-hak konstitusionalitasnya sebagai korban bencana alam. Di samping itu, ke depan diperlukan juga pelatihan advokasi kebijakan bagi warga negara di kawasan risiko bencana agar warga terkait memiliki kemampuan memperjuangkan hak-hak konstitusionalnya sebagai warga negara yang hidup di daerah rentan bencana.
\end{abstract}

Kata Kunci: Hak-hak konstitusional, warga negara, kawasan risiko bencana

\section{Pendahuluan}

Indonesia adalah negara kepulauan yang terletak diantara benua Asia dan Australia serta samudera pasifik dan hindia. Diapit oleh dua lempeng benua serta dua samudera menjadikan letak geografis Indonesia menjadikan wilayah yang rawan terhadap bencana alam seperti tsunami yang diakibatkan oleh gempa di dasar laut (tektonik). Selain itu, wilayah geografis Indonesia dilalui oleh "Cincin Api" atau Ring of Fire yaitu jalur magma bumi yang melingkari samudera pasifik, menjadikan Indonesia memiliki banyak gunung berapi aktif. Selain tsunami dan gempa bumi tektonik, Indonesia juga rawan terhadap gempa bumi bumi yang diakibatkan oleh letusan gunung berapi yang dikenal dengan gempa bumi vulkanik. Letusan gunung berapi menambah daftar bencana alam yang ada di Indonesia.

Selain bencana akibat faktor alam, Indonesia juga tidak luput dari bencana yang diakibatkan oleh kegiatan manusia atau bencana non-alam. Bencana ini diakibatkan oleh aktivitas manusia yang seringkali melebihi batas dan bendampak pada kerusakan ekosistem seperti banjir, tanah longsor, abrasi, erosi, dan kebakaran hutan. Menurut Undang-Undang No. 24 Tahun 2007 tentang penanggulangan bencana, wilayah Indonesia sebagai negara kepulauan memiliki kondisi geografis, geologis, hidrologis dan demografis yang rentan terhadap bencana alam dan non alam sehingga menjadikan Indonesia sebagai negara rawan bencana. Letak geografis Indonesia berada pada pertemuan tiga lempeng bumi yaitu lempeng Eurasia, lempeng Pasifik, dan lempeng Indo-Australia yang seringkali mengakibatkan guncangan gempa bumi akibat adanya aktivitas lempeng-lempeng tersebut atau disebut sebagai gempa tektonik. Bencana ini dapat meluluhlantakan struktur kehidupan warga negara. Selain mengakibatkan korban jiwa, 
bencana dapat berdampak pada terganggunya perekonomian masyarakat. Oleh sebab itu, negara memiliki kewajiban untuk memulihkan hak-hak warga negara pasca terjadinya bencana agar dapat kembali kepada kehidupan seperti semua.

Sebagai warga yang menjadi anggota sebuah negara, kita memiliki hak-hak dan kewajiban sebagai warga negara yang diatur dalam hukum dan wajib dipenuhi oleh negara, termasuk hakhak serta kewajiban pasca terjadinya bencana. Hal tersebut diatur dalam Undang-Undang Dasar (UUD) serta peraturan perundang-undangan dibawahnya. Berdasarkan latar belakang tersebut, maka rumusan masalah pada makalah ini adalah apa saja hak-hak warga negara yang wajib dipenuhi oleh negara pasca terjadinya bencana berdasarkan Undang-Undang Dasar 1945? Apakah masyarakat sekitar lereng gunung Merapi, khususnya Sleman mengetahui hak-hak tersebut?

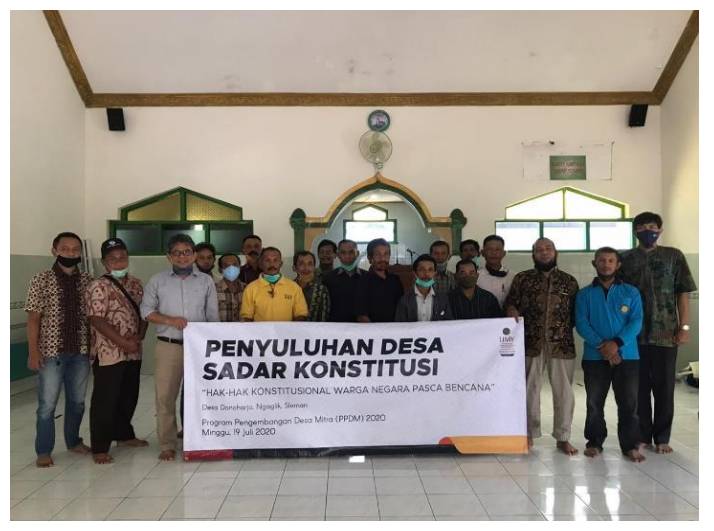

Gambar 1. Pelaksanaan penyuluhan kepada warga di desa Donoharjo

\section{Metode Penelitian}

Kajian ini dilakukan di Desa Donoharjo, Kecamatan Ngaglik, Kabupaten Sleman, D.I. Yogyakarta. Metode penyuluhan dilakukan terhadap kelompok warga tani (lihat Gambar 1). Penyuluhan tentang kebencanaan dan hak-hak konstitusi warga negara dilakukan bersamaan dengan pengukuran indek pemahaman terhadap hak-hak hak-hak konstitusional warga negara di kawasan risiko bencana. Indek ini disusun oleh empat indikator sebagai berikut:

1. Pengetahuan tentang kebencanaan,

2. Pengetahuan tentang peraturan kebencanaan,

3. Pengetahuan tentang tindakan penanggulangan bencana,

4. Pengetahuan tentang hak-hak konstitusi warga negara terdampak bencana.

Masing-masing indikator dijabarkan menjadi beberapa variable yang dapat diukur dengan skor 1 hingga 4 seperti disajikan pada Tabel 1 hingga Tabel 4 . Skor 1 menunjukkan tingkat pemahaman yang rendah, sedangkan skor 4 mengindikasikan tingkat pemahaman yang tinggi.

Tabel 1 Variabel pada indikator pengetahuan tentang kebencanaan

\begin{tabular}{|c|c|c|c|c|}
\hline Pertanyaan & 1 & 2 & 3 & 4 \\
\hline Bagaimanakan tingkat kerentanan daerah Saudara terhadap bencana? & $\square$ & $\square$ & $\square$ & $\square$ \\
\hline Apakah Saudara mengetahui sistem penanggulangan bencana di daerah? & $\square$ & $\square$ & $\square$ & $\square$ \\
\hline
\end{tabular}

Tabel 2 Variabel pada indikator pengetahuan tentang peraturan kebencanaan

\begin{tabular}{|l|l|l|l|l|}
\hline Pertanyaan & 1 & 2 & 3 & 4 \\
\hline $\begin{array}{l}\text { Apakah Saudara mengetahui } \\
\text { peraturan dan perundangan } \\
\text { tentang penanggulangan bencana? }\end{array}$ & $\bigotimes$ & $\square$ & $\square$ & $\square$ \\
\hline Apakah Saudara mengetahui hak- & $\square$ & $\square$ & $\square$ & $\square$ \\
\hline
\end{tabular}


hak konstitusi warga negara bila

mengalami bencana?

Tabel 3 Variabel pada indikator pengetahuan tentang tindakan penanggulangan bencana

\begin{tabular}{|l|l|l|l|l|}
\hline Pertanyaan & 1 & 2 & 3 & 4 \\
\hline $\begin{array}{l}\text { Apakah tindakan pengurangan } \\
\text { risiko bencana telah dilakukan } \\
\text { oleh pemerintah secara maksimal } \\
\text { di daerah Saudara? }\end{array}$ & $\square$ & $\square$ & $\square$ & $\square$ \\
\hline $\begin{array}{l}\text { Apakah tindakan penanggulangan } \\
\text { bencana telah dilakukan oleh } \\
\text { pemerintah secara maksimal di } \\
\text { daerah Saudara saat masa tanggap } \\
\text { darurat bencana? }\end{array}$ & $\square$ & $\square$ & $\square$ & $\square$ \\
\hline $\begin{array}{l}\text { Apakah tindakan pemulihan pasca } \\
\text { bencana telah dilakukan oleh } \\
\text { pemerintah secara maksimal di } \\
\text { daerah Saudara? }\end{array}$ & $\square$ & $\square$ & $\square$ & $\square$ \\
\hline
\end{tabular}

Tabel 4 Variabel pada indikator pengetahuan hak-hak konstitusi warga negara terdampak bencana

\begin{tabular}{|c|c|c|c|c|}
\hline Pertanyaan & 1 & 2 & 3 & 4 \\
\hline Apakah hak-hak Saudara telah dipenuhi pada saat terjadi bencana? & $\square$ & $\square$ & $\square$ & $\square$ \\
\hline $\begin{array}{l}\text { Apakah Saudara merasa perlu menuntut hak-hak konstitusi pada saat terjadi } \\
\text { bencana? }\end{array}$ & $\square$ & $\square$ & $\square$ & $\square$ \\
\hline $\begin{array}{l}\text { Apakah tempat tinggal atau tanah hak milik Saudara harus direlokasi jika terjadi } \\
\text { bencana? }\end{array}$ & $\square$ & $\square$ & $\square$ & $\square$ \\
\hline $\begin{array}{l}\text { Apakah relokasi Saudara harus memberikan keuntungan secara sosial, ekonomi, dan } \\
\text { kepastian hukum? }\end{array}$ & $\square$ & $\square$ & $\square$ & $\square$ \\
\hline
\end{tabular}

\section{HASIL DAN PEMBAHASAN}

\section{A. Bencana Alam dan Non-Alam di Indonesia}

Bencana alam adalah peristiwa atau rangkaian peristiwa yang mengancam dan mengganggu kehidupan dan penghidupan warga negara atau masyarakat yang disebabkan oleh faktor alam maupun faktor non alam. Bencana mengakibatkan timbulnya korban jiwa manusia, kerusakan lingkungan, kerugian harta benda, serta dampak psikologis yang ditimbulkan pasca terjadinya peristiwa bencana tersebut. Bencana dapat dikategorikan ke dalam tiga jenis, yaitu:

1. Bencana alam, yaitu bencana yang terjadi secara alami diakibatkan adanya aktivitas alam seperti gempa bumi, tsunami, gunung meletus, kekeringan, angin topan, dan lainnya;

2. Bencana non-alam, yaitu bencana yang terjadi akibat peristiwa non-alam seperti kegagalan pemanfaatan teknologi, kegagalan modernisasi, epidemi, wabah penyakit, serta kegiatan manusia yang dapat mengubah struktur alam dan mengakibatkan bencana seperti penggundulan hutan yang berdampak pada terjadinya tanah longsor serta tertumpuknya sampah pada sungai yang menghambat aliran dan mengakibatkan banjir;

3. Bencana sosial, yaitu bencana yang diakibatkan oleh konflik sosial antara kelompok atau komunitas masyarakat seperti perang, kerusuhan, terorisme, konflik politik yang mengakibatkan kelaparan, serta konflik-konflik sosial lainnya.

Menurut Undang-Undang No. 24 Tahun 2007 tentang penanggulangan bencana, wilayah Indonesia sebagai negara kepulauan memiliki kondisi geografis, geologis, hidrologis dan demografis yang rentan terhadap bencana alam dan non alam sehingga menjadikan negara Indonesia sebagai negara rawan bencana. Letak geografis Indonesia berada pada pertemuan tiga lempeng bumi yaitu lempeng Eurasia, lempeng Pasifik, dan lempeng Indo-Australia yang seringkali mengakibatkan guncangan gempa bumi akibat adanya aktivitas lempeng-lempeng tersebut atau disebut sebaga gempa tektonik. 
Gempa bumi tektonik yang terjadi di wilayah daratan mengakibatkan kerusakan yang sangat parah dan seringkali memakan banyak korban jiwa akibat minimnya peringatan sebelum terjadinya gempa bumi tektonik tersebut. Berbanding terbalik dengan gempa bumi tektonik yang terjadi di wilayah perairan atau dasar laut, hal ini seringkali tidak menimbulkan kerusakan parah dan hanya berdampak pada getaran rendah saja jika kekuatan gempa (magnitude) tersebut berada pada level aman. Namun, jika magnitude tersebut besar, gempa bumi tektonik tersebut dapat mengakibatkan bencana susulan yaitu tsunami.

Keadaan bencana ini dapat meluluhlantakan struktur kehidupan warga negara. Selain mengakibatkan korban jiwa, bencana dapat berdampak pada terganggunya perekonomian masyarakat. Oleh sebab itu, negara memiliki kewajiban untuk memulihkan hak-hak warga negara pasca terjadinya bencana agar dapat kembali kepada kehidupan seperti semua.

Dalam kasus bencana alam erupsi Gunung Merapi Tahun 2010, Pemerintah Pusat membentuk Tim Rehabilitasi dan Rekonstruksi Wilayah berdasarkan Keppres No. 16 Tahun 2011. Tim tersebut memiliki tugas untuk mengkoordinasikan kebijakan, perencanaan, pelaksanaan, pemantauan, evaluasi serta menetapkan langkah-langkah strategis dalam mengatasi hambatan dalam pelaksanaan rehabilitasi dan rekonstruksi wilayah.

Kasus semburan lumpur panas akibat kelalaian petugas pengebor PT. Lapindo di Sidoarjo, Jawa Timur, dikategorikan sebagai bencana non-alam oleh Pemerintah serta membentuk Tim Nasional Penanggulangan Semburan Lumpur Lapindo berdasarkan Keppres No. 13 Tahun 2006 dan diperpanjang dengan Keppres No. 5 Tahun 2007. Selain itu, Pemerintah membentuk Badan Penanggulangan Lumpur Lapindo berdasarkan Perpres No. 14 Tahun 2007 (Flamboyan, 2011). Konflik Sampit adalah pecahnya kerusuhan antar etnis migran Madura dan etnis setempat Dayak yang terjadi di provinsi Kalimantan Tengah sepanjang tahun 2001. Berawal dari dua orang suku Madura yang diserang oleh sejumlah warga Dayak, mengakibatkan lebih dari 500 korban jiwa dan 100.000 warga migran Madura kehilangan tempat tinggal. Penyelesaian konflik Sampit memakan waktu bertahun-tahun namun dapat diselesaikan dengan jalan damai yaitu rekonsiliasi.

\section{B. Pelaksanaan Program Pengabdian Masyarakat di Asosiasi Kelompok Tani Indonesia Kabupaten Sleman}

Berikut ini akan dideskripsikan secara singkat wilayah dan masyarakat lereng Gunung Merapi Yogyakarta.

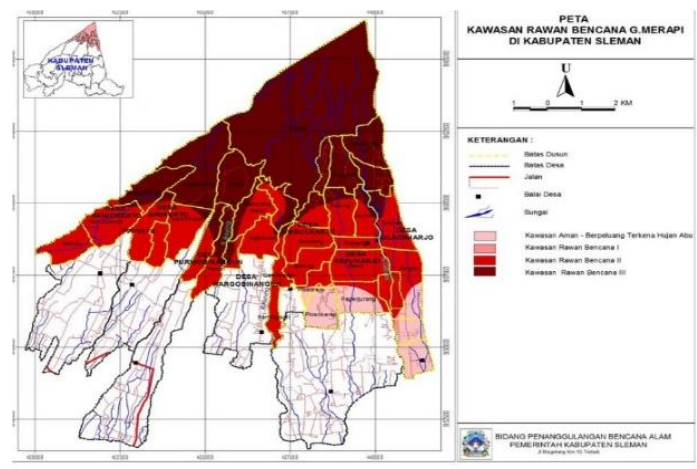

Gambar 2. Peta Kawasan Rawan Bencana Gunung Merapi di Kabupaten Sleman

Kawasan Rawan Bencana (KRB) Gunung Merapi terletak di sekitar lereng Gunung Merapi yang berlokasi di provinsi Jawa Tengah dan Daerah Istimewa Yogyakarta. KRB terbagi tiga zona yaitu Zona KRB III dengan warna merah tua dan luas $120 \mathrm{~km}^{2}$ yang berjarak sangat dekat dengan kawah sehingga menjadi daerah paling rawan dan berpotensi besar mengalami 
terjangan awan panas (aliran piroklastika), aliran lava, lontaran batu pijar, guguran batu pijar dan paparan gas beracun (Isnainiati, 2014).

Zona KRB II Gunung Merapi dengan warna merah dan luas $97 \mathrm{~km} 2$ berjarak sedikit lebih jauh terhadap kawah dibandingkan dengan KRB III. KRB II memiliki peluang untuk terdampak aliran awan panas, paparan gas beracun dan guguran batu pijar meski potensinya lebih kecil dari KRB III, KRB II ini berpotensi besar terpapar hujan abu lebat dan aliran lahar.

Zona KRB I ditandai dengan warna pink dan putih, memiliki luas $31 \mathrm{~km} 2$ yang memiliki jarak paling jauh dari kawah daripada KRB II. KRB I mengerucut pada lembah-lembah sungai yang berhulu di Gunung Merapi khususnya di lereng tenggara, selatan, barat daya dan barat. KRB I memiliki potensi terdampak aliran lahar, kecuali dalam kasus letusan besar. Daerah yang termasuk KRB erupsi gunung Merapi di Provinsi Daerah Istimewa Yogyakarta ada 3 kecamatan, yaitu Cangkringan, Pakem, dan Turi. Untuk demografi penduduk lereng gunung Merapi, mayoritas aktivitas ekonomi masyarakat adalah bercocok tanam, beternak hewan dan pengembang daerah wisata (Widodo, 2017).

Berikut dibawah ini adalah data sebaran penduduk yang tinggal di KRB II dan III berdasarkan pendataan yang dilakukan oleh Pemerintah Kabupaten Sleman pada tahun 2010 silam.

\begin{tabular}{|c|c|c|c|c|c|c|c|c|}
\hline \multicolumn{9}{|c|}{ TABEL DATA SEBARAN PENDUDUK } \\
\hline \multirow[t]{2}{*}{ No. } & \multirow{2}{*}{\multicolumn{2}{|c|}{ Desa/Kecamatan }} & \multirow[t]{2}{*}{ KRB } & \multirow[t]{2}{*}{ Jml KK } & \multicolumn{2}{|c|}{ Jml Penduduk } & \multicolumn{2}{|c|}{ Klp Rentan } \\
\hline & & & & & KRB III & KRB II & $\begin{array}{l}\text { KRB } \\
\text { III }\end{array}$ & KRB II \\
\hline & \multicolumn{2}{|c|}{ Kecamatan Cangkringan } & & & 3668 & 2838 & 953 & 595 \\
\hline \multirow[t]{8}{*}{1.} & Kepuharjo & Kaliadem & III & & 432 & & 118 & \\
\hline & & Petung & III & & 324 & & 79 & \\
\hline & & Jambu & III & & 318 & & 68 & \\
\hline & & Kopeng & II & & & 453 & & 85 \\
\hline & & Batur & II & & & 390 & & 68 \\
\hline & & Kepuh & II & & & 392 & & 92 \\
\hline & & Manggong & II & & & 275 & & 47 \\
\hline & & Jumlah & & & 1074 & 1510 & 265 & 292 \\
\hline \multirow[t]{6}{*}{2.} & Umbulharjo & $\begin{array}{l}\text { Kinahrejo/ } \\
\text { Palemsari }\end{array}$ & III & & 261 & & 54 & \\
\hline & & Pangukrejo & III & & 676 & & 109 & \\
\hline & & Gambretan & III & & 559 & & 117 & \\
\hline & & Pentingsari & II & & & 398 & & 108 \\
\hline & & Gondang & II & & & 627 & & 99 \\
\hline & & Jumlah & & & 1496 & 1025 & 280 & 207 \\
\hline \multirow{5}{*}{3.} & Glagahario & Kalitengah Lor & III & & 470 & & 153 & \\
\hline & & $\begin{array}{l}\text { Kalitengah } \\
\text { Kidul }\end{array}$ & III & & 330 & & 139 & \\
\hline & & Srunen (2009) & III & & 298 & & 116 & \\
\hline & & Singlar (2009) & II & & & 303 & & 96 \\
\hline & & Jumlah & & & 1098 & 303 & 408 & 96 \\
\hline & & & & & & & & \\
\hline & Kecamatan Pakem & & & & 5871 & 1000 & 1774 & 328 \\
\hline \multirow[t]{5}{*}{1.} & Hargobinangun & Kaliurang Timur & III & & 1200 & & 362 & \\
\hline & & Kaliurang Barat & III & & 1600 & & 317 & \\
\hline & & Boyong & III & & 769 & & 261 & \\
\hline & & Ngipiksari & II & & & 1000 & & 328 \\
\hline & & Jumlah & & & 3569 & 1000 & 940 & 328 \\
\hline \multirow{4}{*}{2.} & Purwobinangun & Turgo & III & & 761 & & 124 & \\
\hline & & Kemiri & III & & 625 & & 238 & \\
\hline & & Ngepring & III & & 916 & & 472 & \\
\hline & & Jumlah & & & 2302 & & 834 & \\
\hline \multirow{2}{*}{\multicolumn{3}{|c|}{\begin{tabular}{l|l} 
Kecamatan Turi \\
\end{tabular}}} & & & & & & \\
\hline & & & & & 2013 & 3399 & 1210 & 601 \\
\hline \multirow[t]{2}{*}{1.} & Girikerto & Ngandong Tritis & III & 263 & 915 & & 252 & \\
\hline & & Kemirikebo & III & 176 & 515 & & 177 & \\
\hline
\end{tabular}




\begin{tabular}{|c|c|c|c|c|c|c|c|c|}
\hline & & Nganggring & II & 190 & & 804 & & 275 \\
\hline & & Kloposawit & II & 129 & & 411 & & 117 \\
\hline & & Sukorejo & & 154 & & 549 & & \\
\hline & & Jumlah & & & 1430 & 1764 & 429 & 392 \\
\hline 2. & Wonokerto & Tunggularum & III & & 583 & & & 209 \\
\hline & & Gondoarum & II & & & 576 & 195 & \\
\hline & & Sempu & II & & & 1059 & 586 & \\
\hline & & Jumlah & & & 583 & 1635 & 781 & 209 \\
\hline & TOTAL & & & & 11,552 & 7,237 & 3,937 & 1,524 \\
\hline
\end{tabular}

2. Peta Mitigasi Bencana Erupsi Gunung Merapi

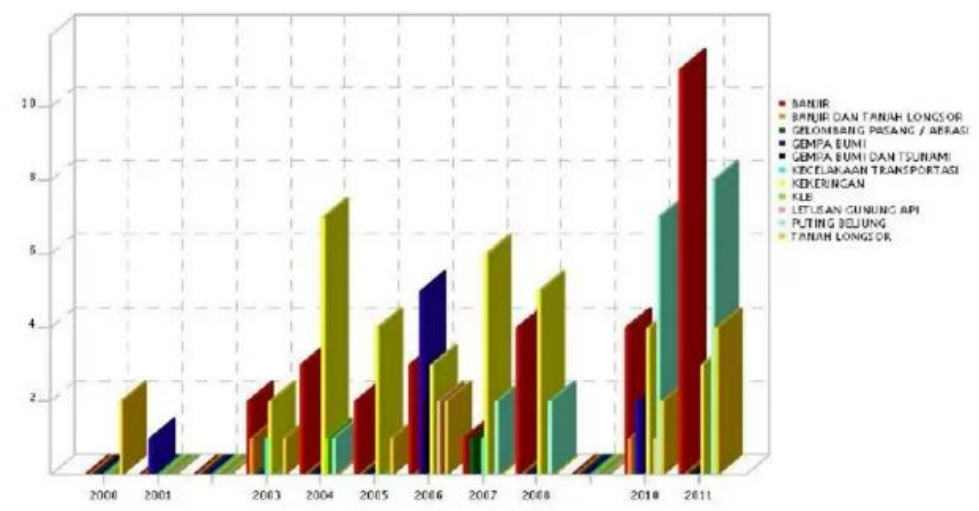

Gambar 3. Data Kecenderungan Kejadian Bencana di DIY

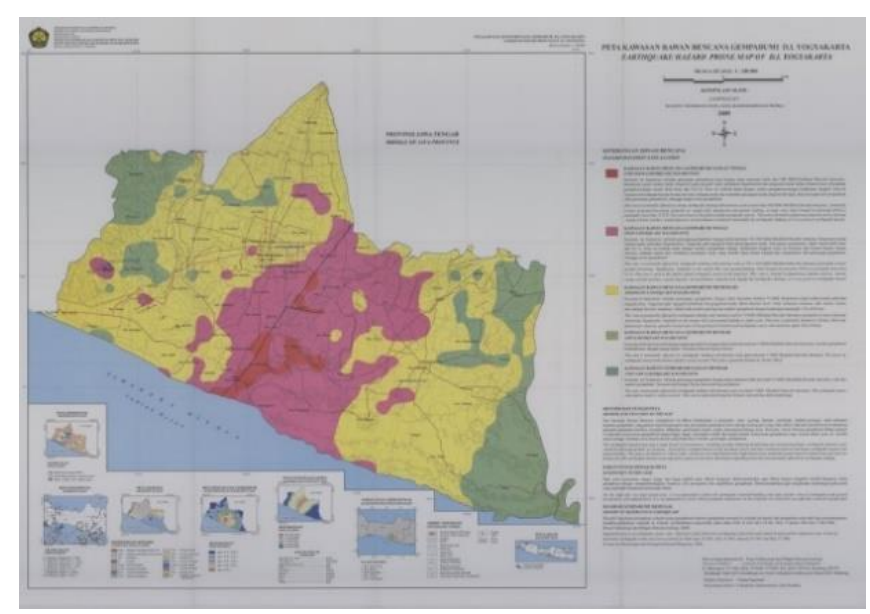


Gambar 4. Peta Kawasan Bencana Gempa Bumi DIY

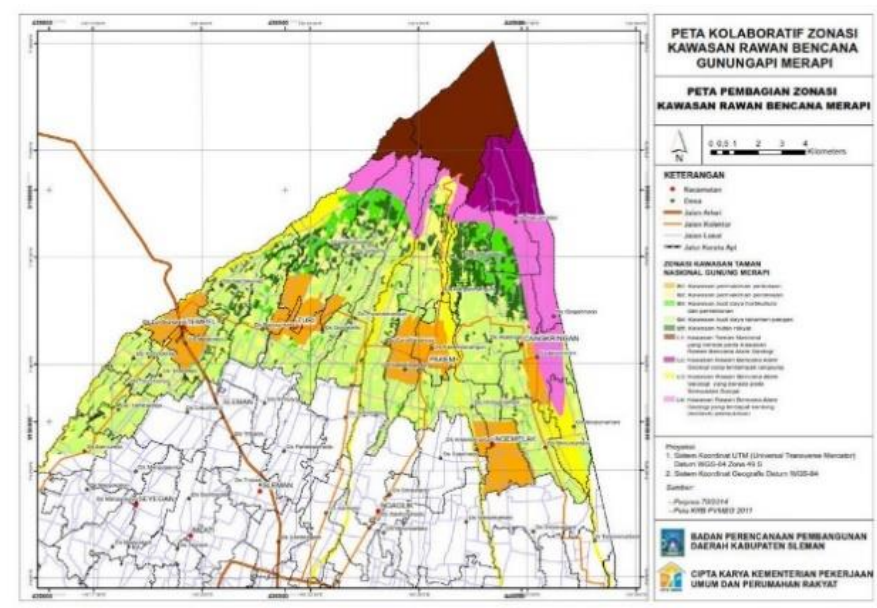

Gambar 5. Peta Kolaboratif Zonasi Kawasan Rawan Bencana Erupsi Gunung Merapi

\section{Pengertian Hak dan Kewajiban Warga Negara Indonesia}

Plato mendefinisikan sebagaimana dikutip oleh Rapar (1988) negara sebagai sebuah organisasi kekuasaan yang dipegang dan digerakkan oleh manusia serta suatu sarana agar dapat mencapai tujuan bersama. Hal ini senada dengan Prof. R. Djokosoetono (1982) yang mengartikan bahwa negara adalah sebuah organisasi manusia atau sekelompok manusia yang berada pada suatu pemerintahan yang sama. Hal ini menciptakan adanya hubungan antara manusia dengan negara tersebut yang kemudian disebut sebagai kewarganegaraan. Menurut Undang-Undang No. 62 Tahun 1958 tentang kewarganegaraan Republik Indonesia, dengan adanya hubungan kewarganegaraan tersebut menimbulkan adanya hak dan kewajiban terhadap negara berkaitan dengan status warga negara yang dimiliki. Oleh karena itu, maka warga negara berhak untuk mendapatkan perlindungan dan melindungi negara, ikut berpartisipasi dalam kegiatan politik serta mendapatkan hak-hak lainnya seperti yang sudah diatur dalam peraturan perundang-undangan yang berlaku.

Perkembangan ilmu ketatanegaraan modern di Indonesia mengenal hak dasar yang dituangkan dalam Undang-Undang Dasar (UUD) 1945 sebagai hak konstitusional. Menurut Prof. Jimly Asshiddiqie (2011), hak konstitusional merupakan hak-hak yang dijamin pemenuhannya dalam dan oleh UUD 1945. Penjaminan hak-hak tersebut baik dinyatakan secara tegas maupun tersirat. Hal ini merupakan bentuk perlindungan hukum dari perbuatan yang dimungkinkan dilakukan oleh pemegang kekuasaan penyelenggara negara dalam hubungan kewarganegaraan atau hubungan warga negara dan negara.

Hak konstitusional tersebut diakui oleh negara atas subjek dari hak konstitusional yaitu warga negara sebagai orang yang diakui secara hukum serta disahkan oleh peraturan perundangundangan sebagai warga negara Indonesia. Oleh sebab itu, seseorang memiliki hak yang sama dalam hal apapun sebagai warga negara Indonesia terlepas dari ikatan ras, suku, agama, dan lain-lain, meskipun dengan beberapa pengecualian yang diatur sebagai hak afirmasi atau hakhak khusus seperti hak masyarakat adat.

Perlindungan dan pemenuhan hak-hak konstitusional merupakan kewajiban seluruh pihak dalam negara termasuk warga negara itu sendiri. Hak konstitusional tidak hanya mencakup mengenai hak, melainkan pula kewajiban, yaitu kewajiban untuk saling menghormati dan menghargai hak konstitusional orang lain. Setiap hak konstitusional warga negara akan menimbulkan kewajiban dasar dan tanggung jawab untuk menghormati hak dasar atau hak asasi orang lain secara timbal balik. Sehingga timbul batasan serta larangan dalam pelaksanaan 
perlindungan hak asasi konstitusional yang ditetapkan dalam undang-undang. Hal tersebut diperlukan agar terdapatnya jaminan pengakuan dan penghormatan atas hak dan kebebasan orang lain, dan untuk memenuhi tuntutan yang adil sesuai dengan pertimbangan moral, keamanan, ketertiban umum dan kepentingan bangsa.

Meskipun tinggal di luar negeri, warga negara tetap memiliki hubungan yang tidak terputus dengan negaranya berkenaan dengan hak dan kewajiban. Hubungan erat antara negara dan warga negara sangat penting dalam keberlangsungan kehidupan negara tersebut. Tidak akan tercipta sebuah negara jika tidak memiliki warga negara, begitu pula sebaliknya. Sebagaimana diatur dalam Konvensi Montevideo 1933 tentang Hak dan Kewajiban Negara menyebutkan bahwa pilar-pilar negara adalah antara lain pemerintah dan warga negara. Sebagai warga yang telah menjadi anggota sebuah negara, maka secara otomatis terikat dengan hak dan kewajiban kepada negara yang harus dilindungi serta dipenuhi. Termasuk hak-hak serta kewajiban yang wajib dipenuhi sebelum, saat dan pasca terjadi bencana alam, mengingat Indonesia adalah negara yang rawan akan bencana alam, non-alam maupun sosial.

Dengan demikian, warga negara Indonesia terikat atas hak-hak yang wajib dipenuhi oleh negara serta kewajiban yang wajib ditunaikan pasca terjadinya bencana. Terlebih bagi penyintas atau survivor yang selamat dari bencana, maka mereka sebagai korban wajib menjadi prioritas sampai pemulihan pasca bencana (Anih, 2017). Dalam konteks ini, negara bertanggungjawab penuh untuk memenuhi tugasnya dalam melindungi warga negara serta memenuhi hak-hak mereka sebagaimana diatur dalam UUD 1945.

\section{Pemetaan Perundangan tentang Hak-Hak Konstitusi Warga Negara dan Warga Terdampak Bencana}

Kejadian bencana memberikan dampak serius bagi golongan rentan seperti perempuan, difabel, dan anak-anak selain warga negara secara keseluruhannya. Bencana ini membutuhkan penanganan yang cepat dan hak-hak warga negara harus segera dipenuhi (Absor, 2011). Secara umum hak-hak konstitusional warga negara telah diatur dalam UUD 1945 serta peraturan perundangan di bawahnya. Setidaknya terdapat 40 hak konstitusional warga negara yang diatur dalam UUD 1945.

Tabel 5 Jenis hak-hak konstitudionsl warga negasra sesuai UUD 1945

\begin{tabular}{|l|l|}
\hline Jeni Hak & Pasal \\
\hline Kewarganegaraan & $\begin{array}{l}28 \mathrm{D}(4), 27(1), 28 \mathrm{D}(1), 28 \mathrm{D} \\
(3)\end{array}$ \\
\hline Hidup & $28 \mathrm{~A}, 28 \mathrm{I}(1)$ \\
\hline Mengembangkan Diri & $28 \mathrm{C}(1)$ \\
\hline Atas informasi & $28 \mathrm{~F}$ \\
\hline Kemerdekaan pikiran & $28 \mathrm{I}(1), 28 \mathrm{E}(1)(2)$ \\
\hline Pekerjaan dan Penghidupan Layak & $27(2), 28 \mathrm{D}(2), 28 \mathrm{I}(1)$ \\
\hline Kepemilikan dan Perumahan & $28 \mathrm{H}(1)(4)$ \\
\hline Kesehatan dan Lingkungan Sehat & $28 \mathrm{H}(1), 28 \mathrm{~B}(1)$ \\
\hline Berkeluarga & $28 \mathrm{~B}(1)$ \\
\hline Kepastian Hukum dan Keadilan & $27(1), 28(1), 28 \mathrm{D}(1)$ \\
\hline Perlindungan diri & $28 \mathrm{G}(1), 28 \mathrm{I}(2)(3), 28 \mathrm{G}(2)$ \\
\hline Memperjuangkan Hak & $28 \mathrm{C}(2), 28 \mathrm{E}(3)$ \\
\hline Hak atas pemerintah & $28 \mathrm{D} 3,27(1)$ \\
\hline
\end{tabular}

Sedangkan peraturan khusus yang mengatur tentang hak masyarakat dan korban bencana diatur dalam UU No. 24 Tahun 2007 tentang Penanggulangan Bencana seperti disajikan pada Tabel 6. 


\begin{tabular}{|l|l|}
\hline Jeni Hak & Pasal \\
\hline Perlindungan sosial dan rasa aman & $26(1) \mathrm{a}$ \\
\hline Pendidikan, pelatihan, keterampilan & $26(1) \mathrm{b}$ \\
\hline Informasi & $26(1) \mathrm{c}$ \\
\hline Kebutuhan dasar & $26(2)$ \\
\hline Ganti rugi karena kegagalan konstruksi & $26(3)$ \\
\hline Bantuan santunan & $69(1)(2)$ \\
\hline
\end{tabular}

\section{Pemahaman Warga terhadap Hak-Hak Konstitusional Mereka Pasca Bencana}

Pemahaman masyarakat terhadap kebencanaan dan konstitusi dinilai dari empat kategori pengetahuan yaitu: (1) pengetahun tentang kebencanaan, (2) pengetahuan tentang peraturan kebencanaan, (3) pengetahuan tentang tindakan penanggulangan bencana, dan (4) pengetahuan tentang hak-hak konstitusi warga negara terdampak bencana (Puri, 2015). Evaluasi dilakukan kepada responden sebanyak dua kali yaitu sebelum penyuluhan (pre-test) dan sesudah penyuluhan (post-test). Gambar 6 hingga 8 memberikan sebaran skor masing-masing indikator. Pada Gambar 9 disajikan matrik indeks pengetahuan masyarakat tentang kebencanaan dan hak konstitusi.

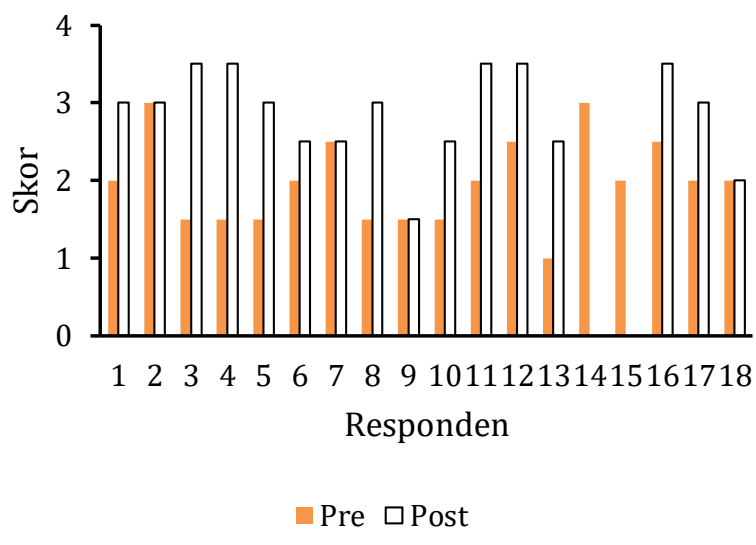

Gambar 6 Sebaran Skor Pengetahuan tentang Kebencanaan

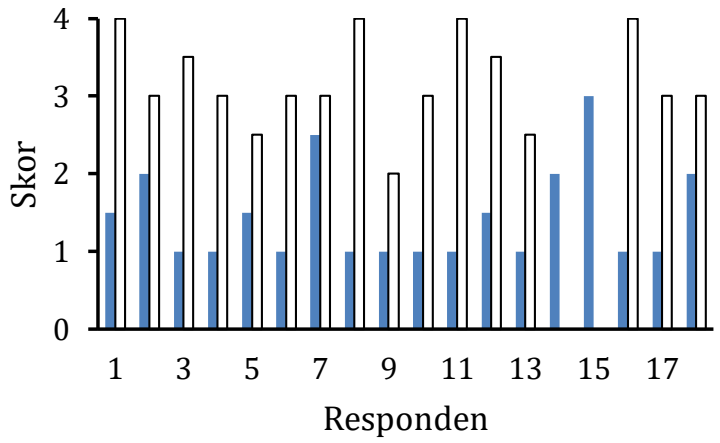

$\square$ Pre $\square$ Post

Gambar 7 Sebaran Skor Pengetahuan tentang Peraturan Kebencanaan 


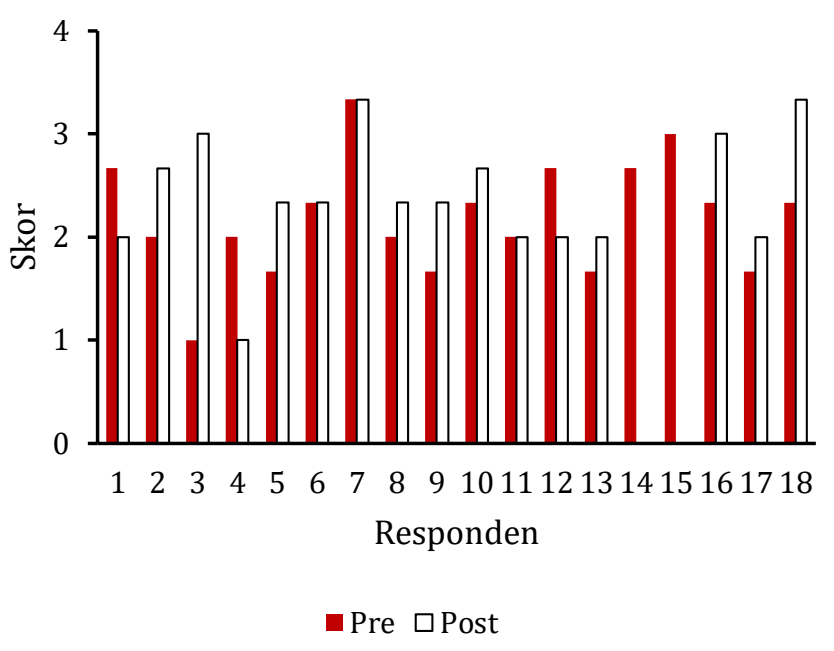

Gambar 8 Sebaran Skor Pengetahuan tentang Tindakan Penanggulangan Bencana

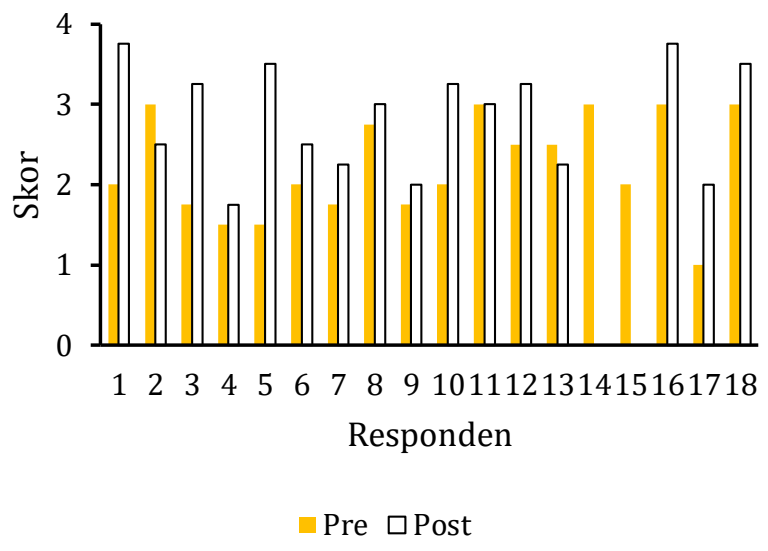

Gambar 9 Sebaran Skor Pengetahuan tentang Hak-Hak Konstitusi Warga Negara Terdampak Bencana

Berdasarkan matrik Indeks Pengetahuan Masyarakat tentang Kebencanaan dan Hak Konstitusi pada Gambar 9, dapat diketahui bahwa pengetahuan masyarakat tentang peraturan kebencanaan memiliki skor yang paling rendah jika dibandingkan dengan ketiga indikator lainnya sebelum dilakukan penyuluhan. Namun setelah dilakukan penyuluhan, indikator pengetahuan warga meningkat hingga mencapai 3,4. Akan tetapi pada indikator pengetahuan tentang tindakan penanggulangan bencana hanya terjadi perubahan yang sangat kecil. Dengan demikian, warga masih belum memahami dengan baik tentang tindakan-tindakan apa saja yang perlu dilakukan oleh pemerintah dan masyarakat untuk melakukan tindakan penanggulangan bencana.

\section{Tantangan dalam Pemenuhan Hak-Hak Konstitusional Warga Pasea Bencana di Kabupaten Sleman}

Salah satu masalah yang terjadi di masyarakat adalah rasa takut ketika terjadi bencana letusan gunung Merapi terulang kembali. Bencana tersebut menjadi momok bagi masyarakat yang telah mengakibatkan korban jiwa yang begitu besar. Masyarakat daerah Sleman khususnya sekitar lereng Gunung Merapi sangat sulit untuk mendapatkan akses peringatan dini apabila akan terjadi letusan untuk menghindari terjadinya korban jiwa atas bencana tersebut. Namun pada kenyataannya, pada tahun 2010, letusan ini menyebabkan 360 orang meninggal dunia. Angka pengungsi mencapai 400.000 jiwa, 2900 rumah rusak, dan total kerusakan 
mencapai 3.5 triliun rupiah. Apabila informasi dini bisa didapatkan oleh masyarakat sekitar, maka maka sistem peringatan dini tersebut mampu menghindari banyaknya korban jiwa. Padahal, hak untuk mendapatkan informasi sebagaimana diatur dalam UUD 1945 Pasal 28F dan Pasal 26 ayat (1) c UU Penanggulangan Bencana, dan hak untuk aman diatur dalam UUD 1945 Pasal 28G ayat (1). Pun untuk perlindungan kesehatan pasca bencana harus diperhatikan dengan seksama oleh pemerintah agar tidak terjadi traumatik atau serangan psikologi lainnya (Firdaus, 2014).

Terdapat pula kaum rentan yang memang harus mendapatkan perhatian lebih dari pemerintah agar hak-hak mereka bisa didapatkan sebagai prioritas dalam pemenuhan haknya, seperti kaum difabel, perempuan, dan lain sebagainya (Meta, 2019). Hal ini karena ketika terjadi bencana pasti akan berpengaruh pada kualitas hidup mereka juga, terlebih untuk kaum rentan akan semakin buruk keadaannya (Widayatun, 2013)

\section{SIMPULAN}

Indonesia sebagai negara yang sangat rawan akan bencana sudah memberikan hak-hak konstitusional yang memadai yang diatur dalam Undang-Undang Dasar 1945. Selain itu, tanggung jawab pemerintah baik pusat maupun daerah sudah diatur juga dalam Undang-Undang Nomor 24 Tahun 2007 tentang Penanggulangan Bencana serta adanya badan khusus yang menangani penanggulangan bencana yang dibentuk berdasarkan Undang-Undang Nomor 8 Tahun 2008 tentang Badan Nasional Penanggulangan Bencana. Dengan demikian, dapat disimpulkan bahwa Indonesia sudah memiliki instrumen yang memadai dalam hal penanggulangan bencana dilihat dari segi perlindungan hukum serta badan khusus yang dapat menanganinya.

Di samping itu, penanggulangan bencana tidak terlepas dari intervensi politik. Dengan demikian, tanggung jawab pemerintah dalam penanggulangan bencana sangat bergantung pada proses birokrasi pada pemerintah dimana hal tersebut menentukan dalam penegakan serta pemenuhan hak-hak konstitusional warga negara terutama masyarakat rawan bencana dan korban bencana alam. Hak-hak konstitusional tersebut wajib dipenuhi oleh pemerintah baik pusat maupun daerah sebelum terjadinya bencana dengan memberikan pendidikan seputar mitigasi bencana di daerah rawan, penganggulangan saat terjadi dan setelah terjadinya bencana tersebut. Oleh sebab itu, upaya pemerintah (political will) dalam konteks kebencanaan harus diprioritaskan untuk pemenuhan hak-hak konstitusional korban bencana, terlepas dari kerugian ekonomi yang dialami oleh negara. Dalam konteks warga Dusun Donoharjo, Kab. Sleman, ternyata banyak masyarakat tidak mengetahui terkait hak-hak dasar yang harus mereka dapatkan ketika terjadi bencana alam letusan gunung Merapi.

Dalam pelaksanaan penanggulangan bencana, Pemerintah maupun Pemerintah Daerah dibantu dengan Badan Nasional Penanggulangan Bencana (BNPB) di tingkat nasional (berdasarkan UU No. 8 Tahun 2008) dan Badan Penanggulangan Bencana Daerah (BPBD) di tingkat daerah (berdasarkan Peraturan Kepala BNPB Nomor 3 Tahun 2008 tentang Pedoman Pembentukan BPBD). Oleh karena itu, perlu ada sosialisasi pemahaman hak-hak warga negara di wilayah risiko bencana secara lebih massif. Di samping itu, perlu juga diberikan pelatihan advokasi hak-hak warga negara agar mereka mampu memperjuangkan hak-hak mereka.

\section{Ucapan Terima Kasih}

Para Penulis mengucapkan terima kasih kepada Universitas Muhammadiyah Yogyakarta (UMY), khususnya Lembaga Penelitian, Publikasi dan Pengabdian Masyarakat (LP3M) UMY yang telah memberikan dukungan dana dalam pelaksanaan kegiatan pengabdian masyarakat ini. 
Ucapan terima kasih juga kami sampaikan kepada Bapak Mulyadi dan segenap anggota dari Asosiasi Agro Puncak Merapi, Yogyakarta. Terakhir, ungkapan terima kasih juga kami haturkan kepada Rofi Aulia Rahman, Yulian Ahmad Hanafi dan Hanum Latifa Kusumastuti yang telah membantu pelaksanaan kegiatan pengabdian masyarakat ini.

\section{Daftar Pustaka}

Anih Suryani, 2017, Pemenuhan Kebutuhan Dasar Bidang Kesehatan Lingkungan Bagi Penyintas Bencana Studi di Provinsi Riau Dan Jawa Tengah, Jurnal Aspirasi 8(1)

Djokosoetono, 1982, Ilmu Negara, Cetakan pertama, Ghalia Indonesia, Jakarta

Dwi Rustiono Widodo, et.al. 2017. Analisis Penyebab Masyarakat Tetap Tinggal di Kawasan Rawan Bencana Gunung Merapi (Studi di Lereng Gunung Merapi Kecamatan Cangkringan, Kabupaten Sleman Daerah Istimewa Yogyakarta). Jurnal Ilmu Lingkungan $15(2)$

Evy Flamboyan Minanda dan Tria Juniati. 2011, Tinjauan Hak Konstitusional terhadap Korban Bencana Lumpur Lapindo, Jurnal Konstitusi 8(3)

Firdaus, 2014, Kebijakan Pemerintah Daerah dalam Pemnuhan Hak Atas Kesehatan Bagi Masyarakat Miskin di Provinsi Sulawesi Selatan. Jurnal HAM 5(1)

Herpita Wahyuni dan Sakir, 2021, Pengarusutamaan Pengurangan Resiko Bencana (PRB) Di Daerah Rawan Bencana Kabupaten Sleman, Jurnal Aristo 9(1)

Jimly Ashiddiqie, 2011, Konstitusi dan Konstitusionalisme Indonesia, Sinar Grafika Offset, Jakarta

J. H. Rapar, 1988, Filsafat politik Plato, Jakarta: Rajawali

Meta Noya Tri Ananda, et.al., 2019, Perlindungan Perempuan Korban Bencana, Social Work Jurnal 9(1)

M. Ulil Absor, 2011, Penanganan Anak dalam Masa Tanggap Darurat Bencana Alam: Tinjauan Konvensi Hak Anak dan Undang-Undang Perlindungan Anak, Jurnal Dakwah 11 (1)

Nur Isnainiati, Muchammad Mustam, dan Ari Subowo, 2014, Kajian Mitigasi Bencana Erupsi Gunung Merapi di Kecamatan Cangkringan Kabupaten Sleman, Indonesian Journal of Public Policy and Management Review 3(3)

Puri Bhakti Renatama, Yoyon Suryono, 2015, Evaluasi Pelaksanaan Program Pelatihan Wajib Latih dan Gladi Lapang Bagi Masyarakat Kawasan Rawan Bencana Merapi, Jurnal Pendidikan dan Pemberdayaan Masyarakat, Vol.2, No.2

Widayatun dan Zainal Fatoni, 2013, Permasalahan Kesehatan dalam Kondisi Bencana: Peran Petugas Kesheatan dan Partisipasi Masyarakat, Jurnal Kependudukan Indonesia 8(1)

Undang-Undang Dasar Negara Republik Indonesia 1945

Undang-Undang Nomor 39 Tahun 1999 tentang Hak Asasi Manusia

Undang-Undang Nomor 24 Tahun 2007 tentang Penanggulangan Bencana

Undang-Undang Nomor 8 Tahun 2008 tentang Badan Nasional Penanggulangan Bencana (BNPB)

Keputusan Presiden Nomor 16 Tahun 2011 tentang Tim Koordinasi Rehabilitasi dan Rekonstruksi Wilayah Pasca Bencana Erupsi Gunung Merapi di Provinsi Daerah Istimewa Yogyakarta dan Provinsi Jawa Tengah

Peraturan Menteri Dalam Negeri Nomor 46 Tahun 2008 tentang Pedoman Organisasi dan Tata Kerja Badan Penanggulangan Bencana Daerah (BPBD)

Peraturan Kepala BNPB Nomor 3 Tahun 2008 tentang Pedoman Pembentukan BPBD 